\title{
Horváth László \\ Igék és igenevek kötött és szabad határozóinak aránya korai középmagyar szövegekben
}

1. Százhúsz évnél is több telt el azóta, hogy Brassai Sámuel akadémiai elöadásában az igét mint a mondat uralkodó középpontját - a Naphoz, bővítményeit pedig (beleértve az alanyt is) a Nap körül keringő planétákhoz hasonlította (1873: 5-6). Mint értekezéséből kitünik, a szerző annak ellenére is bátran vállalta igeközpontú szemléletét, hogy tudván tudta: felfedezése esetleg csak évtizedek múltán számíthat kedvező fogadtatásra (uo. 5.). Az erdélyi polihisztor gondolatai ma már nem idegenek sem a hagyományosabb, sem a modernebb nyelvészeti iskoláktól, sőt az általános és magyar leíró nyelvészeti munkák mellett egyre nagyobb szerephez jutnak a nyelvtörténeti kutatásokban is.

Az utóbbi megállapítás legbeszédesebb bizonyítéka a magyar nyelv múltjára vonatkozó szakirodalomból Forgács Tamás értekezése és vonzatszótára (1996). Számos erénye közül az egyik legfontosabb, hogy gyakorisági szempontokat is érvényesítve vállalkozik nyelvtörténeti szövegvizsgálatra. Ez már csak azért is említésre méltó, mert a TNyt.-nek az igei és az igenévi csoportot bemutató fejezetei (R. Hutás 1995) adósok maradnak a statisztikai adatokkal.

A magyar igék és igenevek vonzatainak és szabad bővítményeinek szövegbeli arányaira vonatkozó statisztikát nem ismerek, erre a kérdésre még Forgács említett könyve (1996) sem tér ki. A névszókkal, a határozószókkal és az alárendelö összetett mondatokkal kapcsolatban a TNyt. II/2 kötetének (1995) S. Hámori Antónia és Haader Lea írta fejezetei a kötött és a szabad szerkesztésmód arányairól is tájékoztatást adnak; megemlítem még S. Hámori Antónia hamarosan megjelenő tanulmányát (1997) a Horvát-kódex melléknévi szerkezeteiröl.

2. Attól kezdve, hogy először hallottam a vonzatosság problematikájáról, fel-felmerül bennem a kérdés: milyen lehet az egyes nyelvtörténeti korszakokban, illetöleg a különféle müfajokban a kötött és a szabad bővítmények aránya? Amikor döntés született a TNyt. munkálatainak folytatásáról, nekem jutott az igei és az igenévi csoport fejezete, így már nemcsak a személyes kíváncsiság, hanem a kutatói feladat is arra ösztönöz hogy megpróbáljak választ adni.

A vizsgálódást mai magyar szövegeken lenne a legcélszerübb kezdeni, mivel a vonzatok és a szabad bővítmények megkülönböztetéséhez, továbbá a kötelezö és a fakultatív vonzatok elhatárolásához a szinkrón anyanyelvi kompetencia biztosabb alap, mint a diakrón pótkompetencia (vö. Forgács 1996:29-31). Miért választottam mégis középmagyar szövegeket? Egyrészt természetesen azért, hogy ilyen módon is ismerkedjem a TNyt. készülö történetének korpuszával; másrészt pedig azért, mert az a véleményem, hogy a középmagyar kor méltatlanul szorul háttérbe nyelvünk történeti vizsgálatában, igyekszem tehát minden lehetöséget megragadni arra, hogy felhívjam a figyelmet erre a hiányosságra (vö. Horváth 1991: 3, 1996:15).

Mostani elöadásom a korai középmagyar időszakból, a XVI. század második feléből származó szövegeken alapul. Ezeket öt müfajból válogattam. Minden müfajt két-két, egyenként 3 ezer $n$ hosszúságú szövegrészlet képvisel: az elbeszélő prózát Heltai Gáspár krónikája és Martonfalvy Imre emlékirata, a fejtegető prózát Bornemissza Péter prédikációja és az Orvosi könyv, a drámát Sztárai Mihály hitvitázó darabja és Ballasi Bálint pásztorjátéka, a perszövegeket úriszéki iratok és az Új Székely Oklevéltár, a missziliseket pedig Telegdy Pál és Telegdy Kata levelei. 
Az igei és igenévi vonzatok és szabad bővítmények arányainak vizsgálatát a határozók körére korlátoztam, mivel az alany, illetőleg a tárgy a mondatban csakis kötött bővítményként szerepelhet. Statisztikám tehát a feldolgozott szövegrészletek kötött és szabad határozóinak arányát tükrözi, megkülönböztetve a kötelező és a fakultatív vonzatokat is. A számláláskor csak a szövegben ténylegesen jelen lévő határozókat vettem figyelembe, az ellipszis miatt „lappangókat” nem. Ezzel már többé-kevésbé azt is elárultam, hogy az elemzés során nem a szerkezeti alaptagból indultam ki, hanem a határozóból, s ahhoz kerestem meg az általa bővített igét vagy igenevet. Úgy vélem, sem a kopernikuszi világképet, sem Brassai Sámuel nyelvszemléletét nem sérti, ha a „bolygók” irányából tekintünk a „központi égitestre”.

3. Az eredmények bemutatása elött szólnom kell még a vizsgálatból kizárt adatokról, valamint az adatszámlálás és a kötöttség szerinti osztályozás néhány elvéröl, módszerért. Itt köszönöm meg azokat a hasznos tanácsokat, melyeket munkám során Haader Leától és Kugler Nórától kaptam.

a) a nyelvtanírás és az egyetemi nyelvészeti oktatás (vö. pl. Szemere 1972) egészen az utóbbi évekig nem különböztette meg a határozószókat és a partikulákat. Keszler Borbálát (1995:304-5) és másokat (1. A Keszler idézte szakirodalmat uo. 306-8) követve a partikulákat nem tartom önálló mondatrésznek, így határozónak sem. A határozószó önállóan felelhet kiegészítendő kérdésre, a partikula viszont nem. A kérdéspróba elvégzése után például a következő szócskákat partikulának minősítve kirekesztettem adataim közül: 1588: „holot meg ['még'] helie uolt az ßermirmetessignek" (TelegdyPLev. 19); 1559: "Vallyéc el immar ezis" (Sztárai: IP. 33);- határozószónak tekintettem, így a határozószók közé soroltam viszont ezt: 1559: „mayd le ütöc mellettek a platzaual” (uo. 38).

A statisztikából kimaradtak az inkább kötőszónak, mint határozószónak tekinthető elemek is; például: 1578: „Az mellet szörnyü lator szoc, es ektelen szitkoc iü ki szaiokbol” (Bornemissza: Örd. 211).

Értekezésében Forgács Tamás (1996: 16-21) elvileg elismeri a névszók valenciahordozó szerepét, de praktikus okoból csak igéket és igei frazeologizmusokat szerepeltet vonzatszótárában címszóként. Bemutatja a kopula szerepéről folytatott vitákat is, é - szintén a szótárazás megkönnyítésére - a névszói és a névszói-igei állítmány esetében a kopulát (legyen az akár $\breve{r}$ fokú) nevezi meg valenciahordozóként. Mivel engem lexikográfiai szempontok nem kötöttek, megtehettem, hogy azokban a kifejezésekben, melyeknek az ige kevéssé tartalmas, $\mathrm{s}$ inkább csak a névszó ,igésítésére” szolgál, a határozót a névszó bővítményeként kihagyjam felmérésemből. Két példa: 1575: „E gyermeckel ennekem v t a m vólna” (Heltai: Chron. 81b); 1590: "erreöl tettwnk volt panazt" (ÚSzékOkl. 114). Más jellegü kapcsolat, ha a határozó (elvben) egyaránt tartozhat az igéhez és a névszóhoz; ilyenkor bátran minősíthető az ige bővítményének: 1585: ,ayanlom zolgálatomat Ew Nganak” (Martonfalvy: Eml. 22).

A birtokviszonyt tartalmazó mondatokban olykor nemigen lehet elválasztani a genitivust a dativustól, azaz nehéz eldönteni, hogy névszói vagy igei alaptaggal állunk szemben. Például: 1588: „hogj az Vadsagnak immar uige ßakadna” (TelegdyPLev. 18). Az ilyen adatokat jobbnak látnom mellőzni.

Egyes állandósult szókapcsolatokban a határozót a fỏnév bővítményeként kezeltem: 1592: „Istennek hala ['hála']” (TelegdyPLev. 37). Ha viszont (feltehetőleg az érzelmi telítettség miatt) az ige kimaradt a mondatból, de a vonzatot megkövetelö igekötő jelen van, a vonzott határozót teljes értékü igei bővítménynek tartom: 1590: „Noh hozzá [kb. vágjatok] az lopo beste lelek kuruakhoz" (ÚszékOkl. 114)

Nemrég a Magyar Nyelvőrben folyt vita az összetett jelző problémájáról (Balogh 1996, ill. Lengyel 1996). Ha a való nem vezethető vissza a tartalmas létigére, hanem segédelemként 
pusztán arra szolgál, hogy egy határozói alakú mondatrészt alkalmassá tegyen a jelzői szerepre, akkor igenévi szerkezetről nem beszélhetünk, tehát a számláláskor az efféle adatokat nem vehettem figyelembe: 1590: „valamire valo gondolatjában az alperes [ ... ] tamada reank” (ÚszékOkl. 114). Ellenben akkor, ha a való ténylegesen a van igeneve, jellemző rá a saját határozó: 1585: „[Mi az asszonyunknak] $k w l$ walo [ ... ] Maiorsagat [ ... ] meg tartotok” (Martonfalvy: Eml. 21.)

A statisztika készítésekor a halmozott határozókkal egyetlen bővítményként számoltam; például: 1585 "[Asszonyom] Engewmet penig sok keressel fogadasokkal esmegh papan hagia" (Martonfalvy: Eml. 22). Ugyanígy tettem a kettös, az összakapcsolt és az értelmezőszerü határozókkal: 1600: "naprul napra uarnam az Vr Istentül gjogyulasomat" (TelegdyKLev. 202); 1589: "Ha penigh czak hozad szoltamis fel eößtendöben egyßer" (Balassi: SzKom. 73); 1575: "[Morzsinai] ott lakéc nálloc” (Heltai: Chron. 81b).

Az elemzés egyik legfontosabb kérdése az utaló- és kötőszók kezelése. Ez persze szorosan összefügg azzal is, hogy a gyakorisági vizsgálatban figyelembe vegyük-e a mellékmondat alakjában kifejtett bővítményeket. Úgy döntötte - a bővítmények irányából nézve ez látszik egyszerübbnek és logikusabbna -,hogy mind a főmondat, mind a mellékmondat valamennyi határozóját bevonom a statisztikába, beleértve az utalószó és a vonatkozó kötőszó funkcióját ellátókat is, a mellékmondatot mint egészet azonban nem veszem fel adataim közé. e nehéz és vitatható elhatározás következménye például az, hogy a mellékmondatban az igének két azonos szerepü, mégis külön-külön számításba veendő határozója lehet, ha az egyikük kötőszó: 1575: “midön ŕ Király allŕ iöt vólna ebéd vtán az var piatzára” (Heltai: Chron. 82a).

$\mathrm{Az}$ is előfordult, bár csupán kivételesképpen, hogy a magyar mondatba való szerves beilleszkedése miatt idegen nyelvi kifejezést is teljes értékü határozónak ítéltem, noha a bővítménytől induló elemzésben ez nem egészen következetes megoldás: 1590: "meli SzentMartont Homorod-SzentMartonnak hynak in sede Uduarhely" (ÚSzékOkl. 114).

b) a valenciaelmélet kulcskérdése a bővítménynek kötöttség szerinti osztályozása. Ez elméleti síkon is bonyolult, a konkrét szövegvizsgálatban tovább halmozódnak a problémák, nyelvtörténeti szövegeket elemezve pedig még szinkrón beszélöi kompetenciánk sem ad fogódzót.

Forgács Tamás (1996: 34-44) a MünchK.-ből választott korpuszt vizsválva a mondategységek határainak meghúzása a mondatrekonstrukció (vagyis például az ellipszis miatti hiányok megszüntetése) után - Greule nyomán - az affinitativitás elvét követi a bővítmények osztályozásában: kötelező vonzatnak az adott valenciahorodozó mellett mindig megjelenő bővítményt minősíti, fakultatív vonzatnak az 50\%-nál gyakrabban szereplőt, szabad bővítménynek pedig az ennél ritkábbat. Forgács igyekszik ezt a módszert következetesen, de nem mereven alkalmazni: H. Molnár Ilonát (1969:233) idézve figyelmezteti az olvasót arra, hogy a statisztika olykor megtévesztő lehet, „mert a teljesen szabad bővítmények gyakorisága egy-egy ige mellett sokszor jóval nagyobb, mint a vonzaté".

Részben e csapda, részben szövegrészleteim rövidsége az oka annak, hogy Greule és Forgács módszere helyett inkább Gerhard Helbig (pl. 1978: 144.63) és Komlósy András (1992: 31520) tesztjeit alkalmaztam az elhagyhatósági próbát, a transzformációs mondatpróbát, az igemáspróbát, helyettesítési próbákat stb. Az említett szerzők elismerik, hogy ezek sem oldanak meg minden problémát, és Forgácsnak (1996:28) is igaza van abban, hogy az elemző nehezen szabadulhat saját szinkrón nyelvérzékének fogságából. Ha azonban azt szeretnénk, hogy a kötött és szabad bővítmények arányairól valamikor olyanféle mutatóink legyenek, mint Deme Lászlónak (1971) bizonyos mondatszerkezeti sajátságokról, akkor vállalni kell a tévedés kockázatát is. 
Az elemzési szempontok kiegészítéseként itt említem meg, hogy szerintem a bővítmény kötöttségét esetleg néha maga a müfaj is eredményezheti. Erre a jelenségre a levelekben találtam példát, ahol az egyébként szabad hely- és időhatározó a keltezésben az Irtam, kelt típusú igék mellett kötelező vonzatnak nevezhető: 1592: „Irtam Vardaban Vasarnap 92” (TelegdyPLev. 37); 1588: „Zetemben kólt ma hetfün 88” (uo. 19).

4. Szövegvizsgálati kísérletem eredményeit a mellékelt táblázat összegzi. Az igéhez, illetőleg névszóhoz tartozó kötelező $(=\mathrm{k})$, fakultatív $(=\mathrm{f})$ és szabad $(=\mathrm{sz})$ határozó előfordulási száma alatt az egyes rovatokban százalékarányukat is feltüntetem; a kurzív számok az igei és az igenévi bővítmények részesedését jelzik.

Hasonló felmérések híján az eredményeket egyelőre csak előfeltevésekkel vethetjük össze. A gyüjtés megkezdése előtt például arra számítottam, hogy az elbeszélö prózában sok lesz a hely- és az időhatározó, s ez megnöveli a szabad határozók részesedését; láthatjuk azonban, hogy a szabad határozók aránya a fejtegető prózában és a drámában valamivel nagyobb, mint az elbeszélő prózában.

Az egyes müfajokban megfigyelhető vonzat: a szabad határozó arányok egymáshoz viszonyított különbsége statisztikailag nem számottevő, még a leginkább ellentétes képet mutató fejtegető próza és levél közötti eltérés sem szignifikáns ( $\mathrm{p}>0,05)$.- Az egyes müfajokban belül sem számottevők a különbségek, hiába vannak fölényben például Sztárainál a vonzatok,

Balassinál viszont a szabad határozók.

A csaknem 750 adatra vonatkozó összegzésböl kiderül, hogy a korpusz egészében a vonzatként és a szabad bővítményként szereplő határozók száma nagyjából egyensúlyban van, s ugyanez mondható el a vonzatokon belül a kötelező és a fakultatív határozókról. A kötelező vonzatok részesedése Sztárai drámájában, a fakultatívaké Telegdy Kata levelében, a szabad határozóké pedig Bornemissza és Balassi müveiben a legtekintélyesebb.

5. A bemutatott (szerény terjedelmü) XVI. századi szinkrón metszet a középmagyar kor egészére vonatkozó diakrón összehasonlító vizsgálat részlete. A teljesebb áttekintés a müfajok is pontosabb képet adhat. A korpusznak és az időbeli határoknak a tágítása nyilvánvalóan egyre megbízhatóbbá teheti az eredményeket.

Bár hasznosnak tartom, ha a vonzatosság kérdéseit a bővítmények irányából is szemügyre vesszük, sőt véleményem szerint olykor az alaptag és a bővítmény felöl egy vizsgálaton belül akár váltakozva is indulhatunk (vö. Horváth 1991b), a legcélszerübb, ha - Brassai Sámuel szellemében - az alaptag, vagyis maga az ige az elemzés kezdőpontja és egyben centruma.

A grammatikai kutatások, szövegvizsgálatok folyamán erősen érezhető egy következetes szemléletü, gondosan szerkesztett vonzatszótár hiánya. Írásomat abban a reményben zárom, hogy nem kell rá beláthatatlan ideig várnunk, sőt egyszer talán egy magyar nyelvtörténeti vonzatszótárt is kezünkbe vehetünk. 


\begin{tabular}{|c|c|c|c|c|c|c|c|c|c|c|c|c|}
\hline \multirow[t]{2}{*}{ Korpusz } & \multicolumn{4}{|c|}{ igéhez } & \multicolumn{4}{|c|}{ igenévhez } & \multicolumn{4}{|c|}{ összesen } \\
\hline & $\mathrm{k}$ & f & $\mathrm{sZ}$ & össz & $\mathrm{k}$ & $\mathrm{f}$ & sz & össz & $\mathrm{k}$ & $\mathrm{f}$ & $\mathrm{SZ}$ & össz \\
\hline \multirow{2}{*}{$\begin{array}{l}\text { Heltai:Chron. } \\
\%\end{array}$} & \multirow{2}{*}{$\begin{array}{l}25 \\
30\end{array}$} & \multirow{2}{*}{$\begin{array}{l}18 \\
22\end{array}$} & \multirow{2}{*}{$\begin{array}{l}40 \\
48\end{array}$} & \multirow{2}{*}{$\begin{array}{l}83 \\
90\end{array}$} & \multirow{2}{*}{$\begin{array}{l}2 \\
22\end{array}$} & \multirow{2}{*}{$\begin{array}{l}3 \\
33\end{array}$} & \multirow{2}{*}{$\begin{array}{l}4 \\
44\end{array}$} & \multirow{2}{*}{$\begin{array}{l}9 \\
10\end{array}$} & 27 & 21 & 44 & \multirow[t]{2}{*}{92} \\
\hline & & & & & & & & & 29 & 23 & 48 & \\
\hline \multirow{2}{*}{$\begin{array}{l}\text { Martonfalvy: } \\
\text { Eml. } \\
\% \\
\end{array}$} & \multirow{2}{*}{\begin{tabular}{|c|}
9 \\
16
\end{tabular}} & \multirow{2}{*}{$\begin{array}{l}15 \\
27\end{array}$} & \multirow{2}{*}{$\begin{array}{l}32 \\
\mathbf{5 7}\end{array}$} & \multirow{2}{*}{$\begin{array}{l}56 \\
82\end{array}$} & \multirow{2}{*}{$\begin{array}{c}5 \\
42\end{array}$} & \multirow{2}{*}{$\begin{array}{l}2 \\
17\end{array}$} & \multirow{2}{*}{$\begin{array}{c}5 \\
42\end{array}$} & \multirow{2}{*}{$\begin{array}{l}10 \\
18\end{array}$} & 14 & 17 & 37 & \multirow[t]{2}{*}{68} \\
\hline & & & & & & & & & 21 & 25 & 54 & \\
\hline \multirow{2}{*}{$\begin{array}{l}\text { elbeszélő próza } \\
\%\end{array}$} & \multirow{2}{*}{$\begin{array}{l}34 \\
24\end{array}$} & 33 & 72 & 139 & 7 & 5 & 9 & 21 & 41 & 38 & 81 & 160 \\
\hline & & 24 & 32 & 01 & 33 & 24 & 45 & 15 & 26 & 24 & 51 & \\
\hline Bornemissza: & 13 & 11 & 38 & 62 & 1 & - & - & 1 & 14 & 11 & 38 & 63 \\
\hline $\begin{array}{l}\text { Ord. } \\
\%\end{array}$ & 21 & 18 & 61 & 98 & 100 & - & - & 2 & 22 & 17 & 60 & \\
\hline OrvK. & 16 & 12 & 38 & 66 & 1 & 1 & 1 & 3 & 17 & 13 & 39 & 69 \\
\hline & 24 & 18 & 58 & 96 & 33 & 33 & 33 & 4 & 25 & 19 & 57 & \\
\hline fejtegető próza & 29 & 23 & 76 & 128 & 2 & 1 & 1 & 4 & 31 & 24 & 77 & 132 \\
\hline & 23 & 18 & 59 & 97 & 50 & 25 & 25 & 3 & 23 & 18 & 58 & \\
\hline Sztárai. IP. & 27 & 11 & 36 & 74 & 2 & 1 & 1 & 4 & 29 & 12 & 37 & 78 \\
\hline & 36 & 15 & 49 & 95 & 50 & 25 & 25 & 5 & 37 & 15 & 47 & \\
\hline Balassi: SzKom. & 15 & 15 & 51 & 81 & 1 & 3 & - & 4 & 16 & 18 & 51 & 85 \\
\hline & 19 & 19 & 63 & 95 & 25 & 75 & - & 5 & 19 & 21 & 60 & \\
\hline dráma & 42 & 26 & 87 & 155 & 3 & 4 & 1 & 8 & 45 & 30 & 88 & 163 \\
\hline & 27 & 17 & 56 & 95 & 38 & 50 & 13 & 5 & 28 & 18 & 54 & \\
\hline Úriszék & 20 & 19 & 24 & 63 & 1 & 1 & 1 & 3 & 21 & 20 & 25 & 66 \\
\hline$\%$ & 32 & 30 & 38 & 95 & 33 & 33 & 33 & 5 & 32 & 30 & 38 & \\
\hline ÚszékOkl. & 12 & 10 & 35 & 57 & 4 & 4 & 4 & 12 & 16 & 14 & 39 & 69 \\
\hline & 21 & 18 & 61 & 83 & 33 & 33 & 33 & 17 & 23 & 20 & 57 & \\
\hline perszöveg & 32 & 29 & 59 & 120 & 5 & 5 & 5 & 15 & 37 & 34 & 64 & 135 \\
\hline$\%$ & 27 & 24 & 49 & 89 & 33 & 33 & 33 & 11 & 27 & 25 & 47 & \\
\hline TelegdyPLev. & 22 & 21 & 387 & 4 & 81 & 1 & 2 & 7 & 26 & 22 & 40 & 88 \\
\hline$\%$ & 27 & 26 & 92 & 57 & 92 & 14 & 29 & 8 & 30 & 25 & 45 & \\
\hline TelegdyPLev. & 6 & 23 & 33 & 62 & 1 & 3 & - & 4 & 7 & 26 & 33 & 66 \\
\hline & 10 & 37 & 53 & 94 & 25 & 75 & - & 6 & 11 & 39 & 50 & \\
\hline levél & 28 & 44 & 71 & 143 & 5 & 4 & 2 & 11 & 33 & 48 & 73 & 154 \\
\hline$\%$ & 30 & 31 & 50 & 93 & 45 & 56 & 18 & 1 & 21 & 32 & 47 & \\
\hline összesen & 165 & 155 & 365 & 685 & 22 & 19 & 18 & 59 & 187 & 174 & 383 & 744 \\
\hline & 24 & 23 & 53 & 92 & 37 & 32 & 31 & 8 & 25 & 23 & 51 & \\
\hline
\end{tabular}

